\title{
Wiara - ewangelizja - prawo kanoniczne (Rzymskie sympozjum w Roku Wiary 11-12 kwietnia 2013)
}

Wydział Prawa Kanonicznego Papieskiego Uniwersytetu św. Krzyża w Rzymie zorganizował w dniach 11-12 kwietnia 2013 roku, a więc można powiedzieć w samym sercu Roku Wiary, interesujące sympozjum na temat relacji zachodzących między wiarą, ewangelizacją a prawem kanonicznym (XVII Convegno di Studi. Facoltà di Diritto Canonico: Fede evangelizazione e diritto canonico).

W zapraszającym na to sympozjum depliant wskazano na dwa jego ważne elementy. Po pierwsze, odwołując się do motu proprio Benedykta XVI Porta fidei (nr 9) podkreślono, że jest rzeczą ważną pogłębiać relacje między wiarą a prawem kanonicznym, pokonując przy tym takie nastawienia, które redukowałyby kanonistykę jedynie do czystej techniki, jak i te, które dążą do uznania osłabienia tego prawa w związku z jego relacją z wiarą oraz teologią; przy czym podkreślono, że w tradycji kanonicznej należy odkryć nierozłączność między dobrem wiary oraz wymogami sprawiedliwości kościelnej. Po drugie podkreślono, iż sympozjum to podejmuje zagadnienia, w których uwidacznia się bezpośredni wpływ wiary na prawo kościelne, spośód których należałoby wskazać takie problemy, jak: fundamentalną kwestię dotyczącą relacji wiary i umysłu na polu kanonicznym; zagadnienia prawne dotyczące munus docendi Ecclesiae; prawa i obowiązki wiernych związane 
z ewangelizacją, tak gdy idzie o ich obowiązki kościelne, jak i ich postępowanie w świecie; uznanie oraz ochrona cywilna tożsamości chrześcijańskiej osób i instytucji, które mają inspiracje w wierze; wpływ wiary na funkcjonowanie Kościoła, ze szczególnym odniesieniem do prawa misyjnego oraz instrumentów, które zapewniają wierność doktrynie oraz moralności. Jak zatem widać, mamy do czynienia z problematyką ważną, aktualną oraz merytorycznie bardzo dobrze uszczegółowioną, co niewątpliwie zapowiadało już na wstępie sukces tego sympozjum.

To dwudniowe sympozjum obejmowało cztery sesje, w tym dwie przedpołudniowe oraz dwie popołudniowe, w czasie których wygłoszono w sumie osiem czterdziestopięciominutowych referatów, a którym to sesjom kolejno przewodniczyli: abp Gerhard Ludwig Müller - prefekt Kongregacji Nauki Wiary; kard. Stanisław Ryłko - przewodniczący Papieskiej Rady ds. Świeckich; ks. prof. José Tomás Martín de Agar z Papieskiego Uniwersytetu św. Krzyża w Rzymie oraz kard. Francesco Coccopalmerio - przewodniczący Papieskiej Rady ds. Tekstów Prawnych. Po każdej z czterech sesji odbyła się interesująca dyskusja.

Sympozjum otworzył oraz wprowadził w jego tematykę ks. prof. Luis Navarro - dziekan Wydziału Prawa Kanonicznego PUSC w Rzymie, przede wszystkim ukazując to spotkanie naukowe w perspektywie przeżywanego Roku Wiary oraz nowej ewangelizacji, na temat której obradował ostatni Synod Biskupów w październiku 2012 roku. Wskazał ponadto, że w związku $\mathrm{z}$ tematem sympozjum wraca pytanie $\mathrm{z}$ lat siedemdziesiątych na temat natury prawa kanonicznego oraz na temat relacji dotyczących wiary oraz prawa kanonicznego, podkreślając jednocześnie, że wiara to nie tylko jedna z cnót teologicznych, ale ma ona także wymiar prawny.

Pierwszy referat, zatytułowany „Wiara i rozum w kanonistyce: założenia ontologiczne", wygłosił znany chilijski kanonista, a zarazem główny organizator oraz animator tego sympozjum ks. prof. Carlos José Errázuriz M. Miał on charakter wybitnie spekulatywny i stanowił wprowadzenie o charakterze historyczno-ontologicznym do dalszych referatów, które podejmowały już tematy praktyczne i o dużym znaczeniu społeczno-eklezjalnym. Ponadto miały one ukazać ideę tego sympozjum, czyli odpowiedzieć na pytanie, jak konkretnie łączyć wiarę i prawo kanoniczne. I tak w kolejności zostały podjęte przez powszechnie znanych kanonistów wywodzących się z różnych środowisk naukowych, głównie włoskich oraz hiszpańskich, następujące 
zagadnienia: „Prawda wiary a munus docendi Ecclesiae” - ks. prof. Mauro Rivella; „Prawa i obowiązki wiernych świeckich na płaszczyźnie ewangelizacji: ich uczestniczenie w munus docendi” - prof. G. Feliciani; „Świeccy w Kościele. Od kategorii koncepcyjnej do elementów dynamicznych życia chrześcijańskiego” - prof. Gaetano Lo Castro; „Tożsamość religijna a wolność wyznania: rozważania na temat podburzania do nienawiści, czyli hate speech” - prof. Francisca Pérez-Madrid; „Ochrona inspiracji chrześcijańskiej w instytucjach medycznych, wychowawczych oraz opiekuńczych: przypadek „Obamacare” - ks. prof. Ińigo Martínez-Echevarria; „Prawo misyjne w życiu Kościoła. Zagadnienia otwarte” - ks. prof. Andrea D’Auria oraz „Instrumenty prawne organizacji kościelnej w celu zagwarantowania wierności doktrynalnej oraz moralnej" - ks. prof. Fernando Puig.

$$
* * *
$$

Próbując wyciągnąć w podsumowaniu wnioski z tego interesującego sympozjum, w szczególności dla naszej polskiej rzeczywistości, należałoby podkreślić, że sympozjum to ukazało znaczącą rolę wiernych świeckich $\mathrm{w}$ procesie nowej ewangelizacji. Jednocześnie starało się ukazać, jak winna być poprawnie pojmowana wolność religijna czy też ochrona uczuć religijnych we współczesnej, dość skomplikowanej, a niekiedy wrogiej Kościołowi rzeczywistości, w której ogromną rolę odgrywają nowe środki masowego przekazu sprawiające, że "głupoty” stają się powszechne oraz głośne; mówiąc inaczej są bezkrytycznie uznawane za ważne oraz prawdziwe już poprzez sam fakt, że znalazły się w przestrzeni medialnej. Kompetentne wypowiedzi jasno wskazały, że Kościół nie może poddać się mentalności współczesnego świata, ale musi pozostać wierny Ewangelii. Dla rozwiązywania trudnych dzisiejszych problemów konieczna jest zatem wiara, która posiłkując się rozumem, podpowiada, jak je należy poprawnie rozwiązywać. Niewątpliwie jest to ważna uwaga dla dialogu Kościoła ze światem, w perspektywie szukania tego, co jest słuszne, a więc oparte na prawie naturalnym i ostatecznie służące dobru człowieka, zarówno w perspektywie naturalnej, jak i nadprzyrodzonej. 
